\title{
On the Translation of Subtitles from the Perspective of Cultural Dimensions
}

\author{
Xuedong Shi \\ Foreign Language College, Beijing Information Science \& Technology University, Beijing, China
}

\begin{abstract}
Culture is an extensive concept to people in every country. We can hardly define it exactly or accurately. Though many scholars have been discussed about western culture, Kluckhohn-Strodtbeck's cultural-dimension is one of the commonly used theories when people analyze western culture. In this paper, the author will try to analyze it based on the case study of Desperate Housewives, an American television comedy-drama series with eight seasons and portrayed every aspects of life under the western culture. This paper will choose some typical clips of it to analyze and try to be helpful for communications with western people.
\end{abstract}

Index Terms - western culture, cultural-dimensions

\section{INTRODUCTION}

As cross-cultural communication between China and other countries becomes frequent and goes deeper, more and more foreign movies and TV series have flooded into China. Among them, American movies and TV series are particularly popular. With the popularity of the English language, many young Chinese people prefer to watch the original show with translated subtitles, which they consider as a fashion and a good way of learning English. Consequently, translated subtitles, functioning as a bridge between the original show and the target receptors, become increasingly important. Subtitling, one of the main types of audiovisual translation, has become a hot subject in translation studies attracting more and more attention. However, compared with traditional translation researches, subtitle translation theory is far from mature and systematic.

In order to thoroughly understand western culture, I hope to analyze the clips in Desperate Housewives, an American television comedy-drama series, in this paper. It portrayed every aspects of life under the western culture. Since its premiere, the show enjoys great popularity both at home and abroad. It is the winner of multiple Emmy, Golden Globe and Screen Actors Guild award and a representative series to show western culture. Culture tends to be an extensive concept to people in every country. We can hardly define it exactly or accurately. The reason why people always compare it to an iceberg is that only a small part of culture is visible and the hidden part like foreign culture that beneath the surface is invisible but large. In this paper the author uses Kluckhohn and Strodtbeck's theory-Dimensions of Culture to analyze Desperate Housewives. Dimensions of Culture is a theory that has six dimensions, the nature of people, duty towards others, the relationship with nature, mode of activity, temporal orientation, and privacy of space. It is one of the most influential theories about culture. (Kluckhohn, 1951)

The play has plenty of typical western culture, traditional western thinking, language and action patterns, and so on. For example in Desperate Housewives, there are many kinds of parties, talks about the value of independence, even the discrimination against black people. In this paper the author puts the theory into Desperate Housewives under the help of Kluckhohn and Strodtbeck's value orientations, and try to achieve the final target that find reasons why the western people have a different culture with us and how to treat it in our real life. This paper focuses on analyzing the western culture based on the clips of Desperate Housewives with the help of value orientation method. Under the value orientation method, we can make some prediction of the responds of western people and adjust our behavior before unnecessary conflicts. Finally the author sums up with the theory of Kluckhohn and Strodtbeck's Dimensions of Culture and draw my own conclusions.

\section{LITERATURE REVIEW}

Many famous people have attempted to define the term culture. In other words, language is a component of culture and plays a very important role in culture. Language and culture rely on each other. Without language, culture would be impossible. Language is the base of entire culture, and that it is only in language that culture can be well presented and handed down from generation to generation. On the other hand, language is influenced and shaped by culture; it reflects culture. Language reflects characteristics of culture and predicts the developing orientation of culture. In the broadest sense, language is the symbolic representation of a people. The development of language often embodies the change of culture. Having the backgrounds of history and culture, it compromises the method both to life, living and thinking. So it is quite reasonable to say that learning a language is, in a way, learning the culture and habit of the country where the language is spoken. 
The foundations for VOM were developed in the 1940s and 1950s by anthropologists with the Harvard Values Project. They believed that it is possible to distinguish culture. Another commonly used dimension is Geert Hofstede's Cultural Dimensions. And also, Geert Hofstede's major research is in organizations and cross-cultural groups and this made him the famous pioneer. The founded the systematic framework because he founded and differentiated the cultures in national and organizational aspects. In 1965, Geert founded the personnel research department of IBM Europe. In 1967 he made a large survey study dealing the national values differences across the world in the subsidiaries of the international company. During the survey, he compared many employees of the IBM Company in different countries. Firstly, he did his research in big countries and later he did the same experiments in other 50 countries and three regions, which made it the biggest data base for cross-samples at that time. He then had six dimensions of value, namely, power, collective, uncertainty avoidance, masculinity, temporal orientation and indulgence. (Baker, 1998)

Edward T. Hall, the famous anthropologist presented the terms of high context culture, which means that in the daily communication there a tendency to use the high context messages over the lowers ones. This kind of option of communication styles can be seen in a culture which will provide for in-groups that share the same experiences and expectations. Many things are not said in high context cultures because the culture can explain them. For higher context, the choice of words and phrases is very important because there are many effective words and phrases to in-group, in contrast, what the people in lower context culture need to do is to use the simpler and more explicit words and phrases.( Nida, 2000 )

Dr. Harry C. Triandis is the key pioneers of the field of Cross-Cultural Psychology and he established a clear subject in psychology. His main study concentrates on the relationship between the backgrounds of culture and the human behavior, and the different behaviors between the individuals and groups. The differences include the prejudices and intercultural training for communication in other cultures. (Venuti, 1995)

Triandis noted that the most important cultural dimension in social behavior is individualism vs. collectivism. He points out that cultural and individual level individualism and collectivism are interrelated, even though this relation might not result in a simple one-to-one correspondence. An individual can show both individualistic and collectivistic traits at the same time. At the individual level these concepts are treated as separate dimensions. Different terms are used to describe individual level dimensions. The collectivist side included conformity and security and other collectivist values, which are especially high in East Asian countries, in traditional societies, and in the former communist countries. The collectivist values such as the security and conformity are on the collective side. According to his concept, we can identify the culture into four types: horizontal, vertical, horizontal collectivism and vertical collectivism. (Baker, 1998)

\section{KLUCKHOHN AND StrodtBeck's PRIVACY OF SPACE}

In the society, how can we deal with the space? Who owns the privacy of space and why do people have right to occupy the privacy of space? As we know, the privacy of space is very important, as meetings are only held in closed areas. On the contrary, the alternative aspect will allow people to go the place which is open to all. Kluckhohn uses three orientations: individual, linear and collateral. The American culture characterizes the individual model, in which the family relationship is limited both in intensity and in scope. Rather, the family bond is more intense in the collateral model than the individual one. Compared with the nuclear family in American culture, the immediate family is the main feature in the latter model, which include uncles, grandparents and cousins etc. compared with the above two patterns, the linear pattern is my similar to the collateral, however, it extends wider to the distant relatives. To be more specific, all the people who are related to the family by blood are included, even the ancestors are regarded as the important ones. Of course, all the important decisions cannot be made without consulting the ancestors.

\section{a. Kluckhohn and Strodtbeck's Mode of Activity}

Kluckhohn made the valued personality types the fourth value orientation. In the organization and societies, we may wonder, what is the primary pattern? Being is more important in some societies, during which what you do is less important. While, in other societies, the social status is from the actions rather than the ascribed status---the action-oriented society.

\section{b. Kluckhohn and Strodtbeck's the Nature of People}

Kluckhohn insisted that a society will first tell the nature of a man: good, evil or mixed. But she warns that this kind of predictions may not true or mutable. Because human nature plays a an very important role in our world view, it is quite impossible for use to judge another person without referring to our own nature---- judge other cultures with our own as the norm.

\section{CASE Study---Analyses of Desperate Housewives by Western Culture}

\section{a. Western Culture of Desperate Housewives}

Desperate Housewives, American television comedy-drama series, tell us about four housewives work through their daily lives, secrets, family troubles and so on. It portrayed people in middle class of America, and since its premiere, the show has been well received by viewers at home and abroad. 
In this series we can see some extend of feminist of western culture. In the plot, we can discuss the feminist and individualism in popular western culture. For example, the housewives want the equal opportunity or responsibility to have a job, or build a successful career, take care of the children as well. This series show us the current generation of women in western so we can discuss the feminist based on it.

To study the western culture based on the clips of Desperate Housewives, not only can help me to understand the speaker's way of thinking, but also can make me understand the western culture more deeply and then realize how to get alone with westerners. I can gain a lot of language knowledge through analyze the clips of Desperate Housewives and then learn the theories on cultural difference, especially Kluckhohn and Strodtbeck's value orientations, and finally achieve the final target that put the theory into them, and find reasons why the western people have a different culture with us and proficiency in the use of those theories to analyze text.

For analysis the western culture, we have many of theories to do this. For example, Geert Hofstede's Cultural Dimensions is a theory to analyze the western culture and measure cultural differences. The six dimensions of values he proposed are - power, collectivism, uncertainty avoidance, masculinity, temporal orientation, and indulgence. Use those six dimensions of values to analyze the western culture in desperate housewives I will show the clips about the relationship between four housewives to prove the collectivism (versus individualism), and the relation between husband and wives to discuss power (equality versus inequality) and masculinity (versus femininity), and the way that mother handle the children stuff to talk about indulgence (versus restraint).

High context culture and the contrasting "low context culture" are terms presented by the anthropologist Edward T. Hall. It is also a famous theory of dealing with culture. If I analyze the western culture in desperate housewives with it, I will compare the western culture with our Chinese culture and discuss which is more like low context culture and which is more like the high context culture and what is the reason caused the consequence. In addition, Dr. Harry C. Triandis is one of the key pioneers of the field of Cross-Cultural Psychology, which was established as a distinct discipline within psychology. . And he noted that the most important cultural dimension in social behavior is individualism vs. collectivism. So this is the point to analyze the western culture if I use this theory. The western people are different from us with many aspects. Individualism vs. collectivism may be one of distinct part of them. So I can show the clips of housewives about how to deal with the secrets or troubles whether they are individualism or collectivism. More importantly, in this paper, I will use Kluckhohn and Strodtbeck's value orientations theory to analyze the western culture in desperate housewives, especially the three of them-Privacy of Space, Mode of Activity and the Nature of People. (Baker, 1998)

\section{i. Analysis of Privacy of Space in Desperate Housewives}

In the opinion of Kluckhohn and Strodtbeck's value orientations, people in western culture consider that it is important to have their own space.

For example, in Desperate Housewives Season 8 Episode 10, when Bree wanted to end her life in the hotel, she wanted to die with elegance and grace as always. Bree had everything she needed for an elegant death, except privacy. Because her neighbor Renee broken into her room. And she lost the privacy for some more time since Renee found she wanted to end her life.

"Hello, sunshine. How you feelin' this mornin'?.... You will drive me absolutely crazy."

From the conversation, we can see that Bree told Renee that she wants a privacy space even she felt sad about her life. We can see the right of each citizen to have a place they can call their own is important to western people. However, typically in Chinese culture, we will not do that like Bree. Chinese people tend to tell people what a hard time they are having and in Chinese we say "compare bitterness". In addition, Chinese people will not ask for a private room so directly like Bree, we hold the view that it is impolite to ask people out of our room. So if we company with a foreigner with bad mood, we should give him a private room and if he ask for it directly we should accept it and do not have to worry that why he treat me so rudely.

All cultures have unwritten rules on the distance members maintain from one another. In the U.S. we tend to feel that people want to protect their privacy, and they will tell others directly. So if we have the opportunity to communicate with western people. We should care about the privacy space of them. We should understand the need that western people care about it and obey the norm of it. And try to watch ourselves even we are not talking to the western people directly, because they may notice that and have the bad impression on us. And since space is required by western people, we should be sensitive to this and give it to enough to them if necessary.

With the new multi-method and multi trait approach, this study adopted multiple measures to analyze the value orientations of collectivism and individualism among teenagers under different cultural settings. The study attempted to achieve some progress in both theoretical constructs and research methodology on value orientation. The results showed that 1) subjects of different age groups and from different regions had significantly different value orientations of collectivism and individualism; 2)there were significant different correlations among the four methods (measures), indicating the feasibility of multi-method multi-trait analysis; 3) the comparison between the Chinese and overseas' results of value orientations of collectivism and individualism revealed different patterns. The present study provides useful evidence and theoretical/methodological implications for further research.

ii. Analysis of Mode of Activity in Desperate Housewives

What is the important pattern in the society varies in differ societies. The Nature of People can be understood through 
this way — what is the best mode of activity? There are three ways we can see in different culture — being, doing and becoming. In western culture people pay more attention to the last one. "You told me to shake things up, so I decided to make work a place I want to be. Hope this helps. And remember, you can be anything you wanna be. Nothing is out of reach. Honey, this is how you shake things up? By giving away all the company money? Oh, actually, I was afraid that Patrick would put a stop payment so I decided to start using our personal account. You can be honest with me. Have you been drinking again? people's misery without thinking for one minute how they're suffering. What's crazy is thinking you can find happiness in a paycheck or behind the wheel of a sports car. What's crazy is thinking that you're doing something important with your life just because you're wearing a tie." In this part we can see that after a friend died for others, Carlos began to know that what the nature of people is. American people believed that what a person accomplishes is a measure of his or her worth. So the behave of Carlos was considered to be like a crazy person. He does not want to earn money and accomplish some success in career ant more but to help people in need.

But in the next episode, Gaby told Carlos that "I was wrong. If being a counselor's gonna make you happy, then that's what you should do." We can also draw a conclusion from it that people are hoping to change this culture in America.

\section{iii. Analysis of Nature of People in Desperate Housewives}

How can people judge others' nature and beliefs can be explained as good, bad or combined. Here 'good' is in the traditional sense that most people are basically pretty good at heart; they are born good. And bad means most people can't be trusted. People are basically bad and need to be controlled.

Kluckhohn and Strodtbeck believe in western culture that neither evil nor good can reflect the basic nature of people because they are have some combination-mixed.

In Desperate Housewives Season 8 Episode 1, Carlos was killed a person to try to protect her wife. And other housewives found that and hope to help Carlos avoid going to prison. One of them go move the car off the trail. You gonna be okay? Another said are we really doing this? ...We drive carpool. This is a very bad man. He attacked our friend, and her husband protected her, and now we are gonna protect them."

From this conversation we can see the complication of nature of people. Desperate housewives help each other to get rid of the punishment of law but at the same time they are protect the one they loved. In desperate housewives we can see many times that people go see the priests and confess to them. In Desperate Housewives Season 8 Episode 1, Carlos was very short-tempered lately because he killed a guy. Gaby hoped him to move on with his life. From the above part we can obviously found that western people believe in God and they hope to be a good person through their effort. And people in western culture believe that they can be changed with the right guidance and wanted to be helped with priests. Evil and perfectible was how Kluckhohn described the American view of human nature that had grown out of the Puritan heritage. That heritage dictated that "constant control and discipline as essential if any real goodness is to be achieved and maintained," and that "the danger of regression is always present". From the conversation between Gaby and Carlos, we can obviously found that they believe human should be self-control and discipline and if they did something evil, they should confess to a priest and look for a change. Different from western culture, Chinese people do not have priests to confess, because the Religious doctrines are not commonly accepted by them.

After the final eighth season, Desperate Housewives came to an end on May 15, 2012, and I have watched every single episode of it and get to know some aspects of western culture. A number of parties, different values towards life, emphasis on independence, and the way of education are all different from our Chinese culture to some extent. I hold the idea that if we are trying to understand it and master the knowledge about the value orientation method, the western culture is not difficult to understand.

TABLE:

KLUCKHOHN'S VALUE-ORIENTATION MODEL

DIMENSION VALUE ORIENTATION

\begin{tabular}{|l|l|l||l|l|}
\hline 1. Innate Predisposition & Good (mutable or immutable) & Neither good nor bad (mutable or immutable) & Evil (mutable or immutable) \\
\hline 2. Man's Relations to Nature & Mastery (man over nature) & Harmony (man in nature) & Subjugation (man under nature) \\
\hline 3. Time Dimension & Future-oriented & Present-oriented & Past-oriented \\
\hline 4. Valued Personality Type & Activity & Being-in-Becoming \\
\hline 5. Modality of Relationship & Individual & Collateral \\
\hline
\end{tabular}

The above table is made by Kluckhohn, and we can see the six dimensions from different value orientations directly. With the combination of clips in desperate housewives, we can see that the western culture have some rules and we can predict to some extent and avoid unnecessary conflict. For example, from the daily life of housewives I know that women hope to have the same opportunity to work like men and they believe that they can be successful like men. So when we stay with western people, we should get rid of the traditional thinking of woman Chinese culture and show the respect of them. Also, we can see that the nature of people is complicated. We cannot simply say whether we are evil or good. When they decide to do something they consider it from different aspect and finally decide what to do.

In addition, we can see that most people still have American dream, they want the opportunity for prosperity and success and believe that a person accomplishes is a measure of his or her worth. If one denies this conception, people will consider him as a crazy person. We can predict this phenomenon from the value orientation method, because 
American people think highly of action, they hold the view that people should keep working and make the change in business. Also in value orientation method, we should especially pay attention to the privacy they need, if we have business with western people.

\section{CONCLUSION}

Along with the globalization, we have more opportunities to communicate or cooperate with western people, so it is important for us to not only master the basic language of English but also get to know the western culture and try to understand it. The author holds the idea that if we hope to communicate with people in western cultures and avoid unnecessary conflicts, we should master the value orientation method because it can predict some responds of western people. If we adopt this method in our daily communication with western people, it may guide us how to behave properly.

Through the analysis, my understanding of western culture was improved through the guidance of theories and the author has found proper way to do deal with western people. The first thing we should do is to learn western culture but this is not the point. His purpose is that we should try to understand western culture through their history or other theories such us the value orientation method, and make some predictions of their responds and change the improper behaviors in front of western people and to be harmony in communication. After adopting the value orientation method, we may found that it is not difficult to understand the western culture.

\section{REFERENCES}

[1] Baker, Mona. (1998) Routledge encyclopedia of Translation Studies, London and New York: Routledge.

[2] Claire Kramsch. (2000). Language and Culture. Shanghai: Shanghai Foreign Language Education Press

[3] Edward, Twitchell Hall. (1976). Beyond Culture. New York: Anchor Books.

[4] Geert, H Hofstede. (2001). Culture's consequences. London: Sage Press

[5] Hawkes, David. (1973). The Story of the Stone, Great Britain: Penguin Group

[6] Kluckhohn, Clyde. (1951). Values and Value-orientations in the Theory of Action. MA: Harvard University Press.

[7] Newmark, Peter. (2001). A Textbook of Translation, Shanghai: Shanghai Foreign Language Press

[8] Newmark, Peter .(1991). About Translation, Clevedon: Multilingual Matters Press

[9] Nida, Eugene A. (2000). Language, Culture, and Translating. Shanghai: Shanghai Foreign Language Education Press.

[10] Nida, Eugene A. (1964). Toward a Science of Translating. Leiden: E.J.Brill.

[11] Venuti, Lawrence. (1992). Rethinking Translation: Discourse, Subjectivity, Ideology, London and New York: Routledge.

[12] Venuti, Lawrence. (1995). The Translator's Invisibility. London and New York: Routledge.

[13] Venuti, Lawrence. (1998). The Scandals of Translation, London and New York: Routledge.

Xuedong Shi was born in Huhhot, Inner Mongolia, China in 1974. He received his MA degree in translation in Middlesex University, Britain, in 2004. He is currently a lecturer in the Foreign Language Department, Beijing Information Science University, Beijing, China. His academic research mainly focuses on translation and applied linguistics. 